\title{
Psychological Problems of Parents of MR Children
}

\author{
${ }^{1}$ Dr. Sapna Singh* ${ }^{2}$ Dr. Shama Lohumi \\ ${ }^{1}$ Professor, Head of Department Paediatric Nursing, Narayan Nursing College, Gopal Narayan Singh University, Rohtas, Bihar. India. \\ ${ }^{2}$ Principal, Shivalik Institute of Nursing, Sanjauli, Shimla, Himachal Pradesh. India. \\ DOI: 10.29322/IJSRP.11.10.2021.p11834 \\ http://dx.doi.org/10.29322/IJSRP.11.10.2021.p11834
}

\begin{abstract}
The parents of mentally retarded children have various psychological problems. Parents require emotional strength and flexibility in order to raising a child who is mentally challenged. Parents of mentally challenged children commonly experience a gamut of emotions over the years. The aim of the study was to assess psychological problems among parents of mentally retarded children. 250 parents of mentally retarded children were selected through purposive sampling technique from different MR centres of selected Urban area of North India. Standardized tools was used as P.G.I. Health Questionnaire N1 (Verma, Wig \& Pershad) for assessing the psychological problems. Result shows that majority of parents had psychological problems. Conclusion of the study suggests that there was need for early diagnosis, prompt treatment and counselling for psychological problems in parents. Level of mental retardation of the children had great effect on psychological problems of parents.
\end{abstract}

Index Terms- Psychological Problems, Parents, Mentally Retarded Children.

\section{INTRODUCTION}

$M$ ental retardation is a condition of incomplete development of the mind, which is especially characterized by impairment of skills, manifested during the development periods, which contribute to overall level of intelligence. The diagnosis of mental retardation in a child can trigger a range of emotional responses in parents and across family systems, which in turns attribute into some level of psychological problems.

A mentally retarded child in a family is usually a serious stress factor for the parents. It often requires a reorientation and re-evaluation of family goals, responsibilities and relationships. In India, the majority of persons with mental retardation have traditionally been cared for by their families. In today's modern society this home-based care has resulted in many adverse consequences. Factors such as changes in the social system (e.g. breaking up of joint families) and the economic system (e.g. unemployment, inflation, etc.) have contributed to the stress that parent of mentally retarded children experience (Majumdar, M., Pereira, Silva. D. Y., \& Fernandes, J, 2005).

Parents perceive the handicapped child as an extension of themselves and may feel shame, social rejection, ridicule and embarrassment. Parental reactions may be affected by economic status, personality traits and marital stability. In short, an initial parental response may be a form of emotional disintegration. Parents may avoid social contacts due to fear of embarrassment or rejection. They may hardly find time for recreation or leisure due to caring responsibilities. Some parents may feel rejected or neglected from their own family members, and some may get adequate support also.

\section{NEED OF THE STUDY}

Raising a child who is mentally Retarded requires emotional strength and flexibility. The child has special needs in addition to the regular needs of all children, and parents can find themselves overwhelmed by various medical, caregiving and educational responsibilities. Whether the special needs of the child are minimal or complex, the parents are inevitably affected. Support from family, friends, the community or paid caregivers is critical to maintaining balance in the home (Boyd, J. Lucy., 2017).

Parents with Mentally Retarded Children experience stress in attempting to meet the socialization needs. Lack of socialization may be due to specific skill deficit of the disabled child or be attributed to negative attitudes among community members, neighbours and relatives towards the persons with disability and their family. The inability to share the problems exists through no fault of the parents, or of the general public. It is simply the result of having looked upon mental abnormalities with superstition, with fear, with ignorance of true facts.

The commonest psychological problems which parents focus are like physical care, health, career, support, finance, social, embarrassment, relationship, and sibling effect. Parents require emotional strength and flexibility in order to raising a child who is mentally challenged. Whether the special needs of the child are minimal or complex, the parents are inevitably affected. Support from family, friends, the community or paid caregivers is critical to maintaining balance in the home. Parents of mentally challenged children commonly experience a gamut of emotions over the years. They often struggle with guilt (Boyd 2017).

\section{RESEARCH STATEMENT}

A study on psychological problems of parents of mentally retarded children at selected MR centre of Urban area in North India.

\section{OBJECTIVES OF THE STUDY}

- The objective of the study was to assess the psychological problems among parents of mentally retarded children.

- To associate the psychological problems of parents of mentally retarded children with the selected sociodemographic variables. 


\section{MATERIAL AND METHODS}

\section{Research Approach}

Quantitative Research Approach was used for present study.

\section{Research Design}

Non-Experimental Descriptive research design was used.

\section{Population of study}

The data was collected from 250 parents out of which 137 were mothers and 113 were fathers.

\section{Sampling technique}

In the present study purposive technique was used to select the sample from different MR centers.

\section{Research Setting}

The study was conducted in different MR centers of Selected Urban area of North India.

\section{Sampling Criteria \\ Inclusion Criteria}

- Parents(mother/father) who are taking care of their mentally retarded children.

- Mentally retarded children below 18 years of age.

\section{Exclusion Criteria}

- Parents of profound level of mentally retarded children.

\section{Tools of data collection}

A standardized tool was given to the subjects and the data was collected from the subjects on the basis of the same.

Section A: consists of 11 items describing the sociodemographic variables of parents such as age, sex, marital status, education, occupation, monthly family income, religion, type of the family and variables of child were age of child, sex of child \& level of mental retardation. Section B: has P.G.l. General Health Questionnaire (N-1). A well experienced clinical psychologists and psychiatrists of PGI i.e. Verma, Wig and Pershad (1985) have developed and standardized this tool.

The scale PGI Health Questionnaire N-1 have two parts:

Part A-consists of items from 1 to 16 related to physical aspects of neuroticism

Part B- consist items from 17-38 related to psychological aspects of neuroticism (feelings as anxiety, worry, fear, anger, frustration, envy, jealousy, guilt, d epressed, mood and loneliness).

The items were scored on 3-point scale (always sometimes never). The total score for all subscales is 76 in total aspects of the neuroticism. Items were scored as follows: always 2 , sometimes 1 and never 0 . The greater score shows more neurotic tendencies among the subjects. All participants were given questionnaire in Hindi and English.

\section{RESULTS OF THE STUDY}

Table no. 1 shows distribution of socio demographic variables in terms of frequency and percentage were shown.

Age: Majority of parents (62\%) were under age group of 3540 , followed by $26 \%$ were under the age group $40-45$, followed by $8 \%$ under age group $45-50$ and the least $5 \%$ were upto the age group 35

Sex: Majority of parents (55\%) were female and $45 \%$ were male

Marital Status: Majority of parents (96\%) were married, the least $2 \%$ were divorced \& $2 \%$ were separated and none of them were single \& widowed.

Educational Status: Majority of parents (56\%) were graduate, followed by $32 \%$ Post Graduate, followed by $11 \%$ had a diploma and the least $1 \%$ were secondary educated but none of them were only matric educated as well as only primary educated.

Occupation: Majority of parents $(60 \%)$ were private employee, followed by $27 \%$ were homemaker, followed by $10 \%$ were government employee and the least $3 \%$ were self employed and none of them were working on daily wages.

Monthly Family Income: Majority of the parents monthly family income (65\%) was between 20001-30000, followed by $23 \%$ was between 15000-20000 and the least $12 \%$ was between 20000 40000 .

Religion: Majority of the parents (55\%) were Hindu, followed by $25 \%$ were Sikh, followed by $8 \%$ were Christian and the least $6 \%$ were Muslim and other.

Type of Family: Majority of the parents (80\%) belonged to nuclear family and $20 \%$ belonged to joint family.

Age of The Child: Majority of study parent's children (40\%) were under age group of 8-9 and the least $20 \%$ were under the age group $6-7,10-11 \& 12$ and above.

Gender of The Child: Majority of parent's children (68\%) were male and $32 \%$ were female.

Level of Mental Retardation: Majority of parent's children (72\%) were mild MR, 24\% were moderate MR and the least $4 \%$ were severe MR.

Table 1: $N=250$

\begin{tabular}{|l|l|l|l|}
\hline $\begin{array}{l}\text { SOCIO } \\
\text { VARIABLES }\end{array}$ & DEMOGRAPHIC & Frequency(n) & Percentage (\%) \\
\hline AGE & UP TO 35 & 12 & $5 \%$ \\
\cline { 2 - 4 } & $35-40$ & 154 & $62 \%$ \\
\hline
\end{tabular}




\begin{tabular}{|c|c|c|c|}
\hline & $40-45$ & 65 & $26 \%$ \\
\hline & $45-50$ & 19 & $8 \%$ \\
\hline \multirow[t]{2}{*}{ SEX } & Female & 137 & $55 \%$ \\
\hline & Male & 113 & $45 \%$ \\
\hline \multirow{5}{*}{$\begin{array}{l}\text { MARITAL } \\
\text { STATUS }\end{array}$} & Single & 0 & $0 \%$ \\
\hline & Married & 239 & $96 \%$ \\
\hline & Divorced & 05 & $2 \%$ \\
\hline & Separated & 06 & $2 \%$ \\
\hline & widowed & 0 & $0 \%$ \\
\hline \multirow[t]{7}{*}{ EDUCATION } & Primary & 0 & $0 \%$ \\
\hline & Matric & 0 & $0 \%$ \\
\hline & Secondary & 2 & $1 \%$ \\
\hline & Diploma & 27 & $11 \%$ \\
\hline & Graduate & 139 & $56 \%$ \\
\hline & Post Graduate & 81 & $32 \%$ \\
\hline & $\begin{array}{l}\text { Post graduate and } \\
\text { above }\end{array}$ & 1 & $0 \%$ \\
\hline \multirow[t]{5}{*}{ OCCUPATION } & Homemaker & 68 & $27 \%$ \\
\hline & Daily wages & 0 & $0 \%$ \\
\hline & $\begin{array}{l}\text { Government } \\
\text { Employee }\end{array}$ & 24 & $10 \%$ \\
\hline & Private employed & 149 & $60 \%$ \\
\hline & Self employed & 9 & $3 \%$ \\
\hline \multirow{3}{*}{$\begin{array}{l}\text { FAMILY } \\
\text { INCOME (per } \\
\text { month) }\end{array}$} & $15000-20000$ & 58 & $23 \%$ \\
\hline & 20001-30000 & 163 & $65 \%$ \\
\hline & $20000-40000$ & 29 & $12 \%$ \\
\hline \multirow[t]{5}{*}{ RELIGION } & Hindu & 137 & $55 \%$ \\
\hline & Muslim & 15 & $6 \%$ \\
\hline & Sikh & 63 & $25 \%$ \\
\hline & Christian & 21 & $8 \%$ \\
\hline & Others & 14 & $6 \%$ \\
\hline \multirow{2}{*}{$\begin{array}{ll}\text { TYPE } & \text { OF } \\
\text { FAMILY } & \end{array}$} & Nuclear Family & 200 & $80 \%$ \\
\hline & Joint Family & 50 & $20 \%$ \\
\hline \multirow{4}{*}{$\begin{array}{l}\text { AGE OF THE } \\
\text { CHILD }\end{array}$} & $6-7$ & 51 & $20 \%$ \\
\hline & $8-9$ & 100 & $40 \%$ \\
\hline & $10-11$ & 49 & $20 \%$ \\
\hline & 12 and above & 50 & $20 \%$ \\
\hline \multirow{2}{*}{$\begin{array}{l}\text { GENDER } \\
\text { THE CHILD }\end{array}$} & Male & 171 & $68 \%$ \\
\hline & Female & 79 & $32 \%$ \\
\hline
\end{tabular}




\begin{tabular}{|l|l|l|l|}
\multirow{4}{*}{ LEVEL OF MR } & Mild & 180 & $72 \%$ \\
\cline { 2 - 4 } & Moderate & 61 & $24 \%$ \\
\cline { 2 - 4 } & Severe & 9 & $4 \%$ \\
\hline
\end{tabular}

Table no. 2 and Figure no. 1 depicts that majority of study subject's psychological problems score $85.6 \%$ was average and $14.4 \%$ was low but none had a high score for psychological problems.

Table 2: Frequency and percentage of psychological problems score in parents of mentally retarded children

\begin{tabular}{|l|l|l|}
\hline \multicolumn{3}{|l|}{ CRITERIA MEASURE OF PSYCHOLOGICAL PROBLEMS SCORE } \\
\hline Category Score & Frequency & Percentage \\
\hline High(51-76) & 0 & 0.0 \\
\hline Average(26-50) & 214 & 85.6 \\
\hline Low(0-25) & 36 & 14.4 \\
\hline
\end{tabular}

Maximum Score $=76$ Minimum Score $=0$

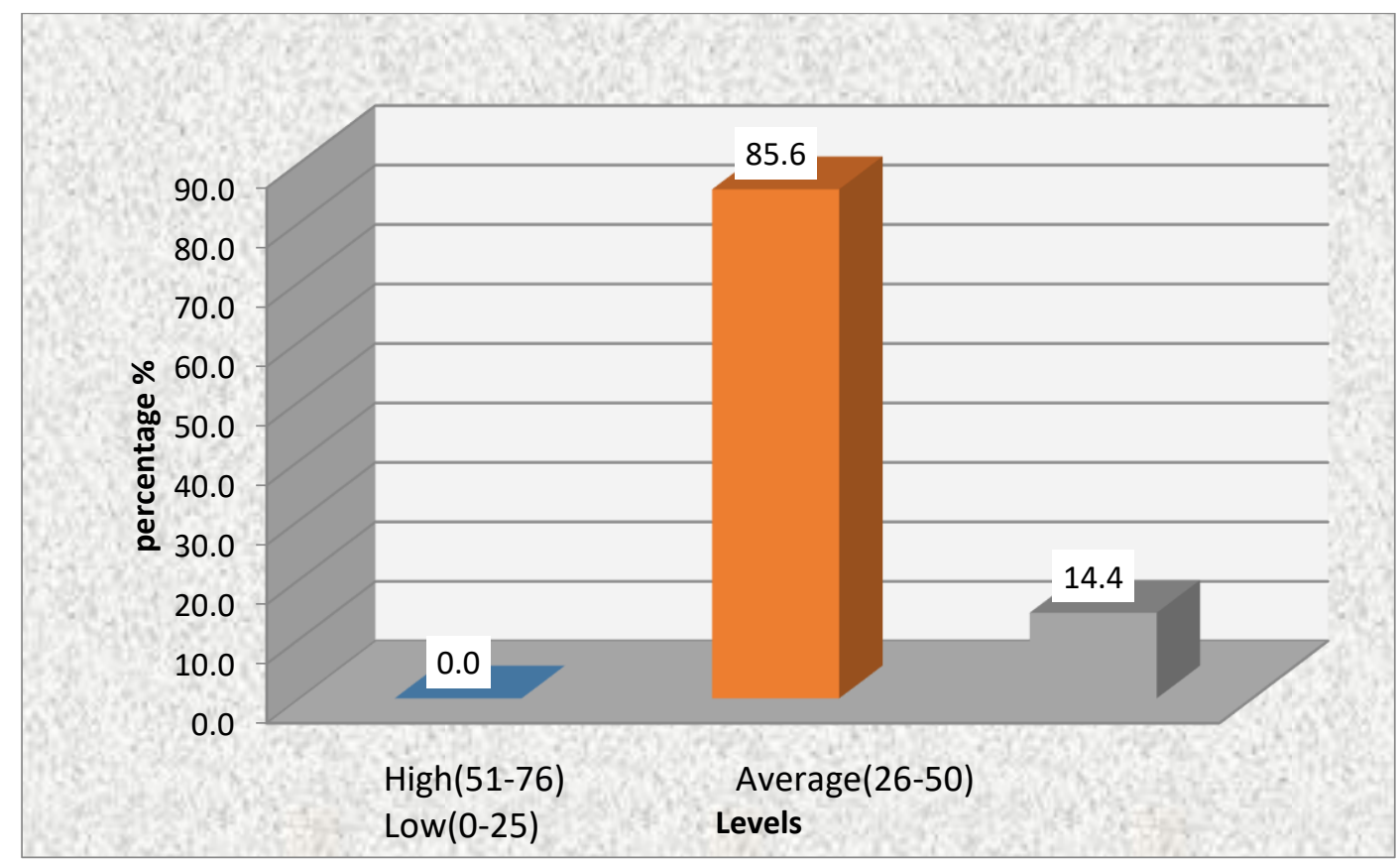

Figure 1 Percentage of psychological problems score in parents of mentally retarded children

Table no. 3 and figure no. 2 shows descriptive statistics of area wise analysis of psychological problems score in parents of mentally retarded children where in Part A the mean was 14.95 , standard deviation was 4.253 , median score 15 , maximum possible score was 32 and mean percentage was $46.71 \%$. Whereas Part B the mean was 17.48 , standard deviation was 4.432 , median score 19 , maximum possible score was 32 and mean percentage was $39.73 \%$ and Psychological problems score the mean was 32.43 , standard deviation was 6.312 , median score 32 , maximum possible score was 76 and mean percentage was $42.67 \%$

Table 3: Descriptive Statistics of Area wise analysis level of psychological problems score in parents of mentally retarded children

$\mathbf{N}=\mathbf{2 5 0}$ 


\begin{tabular}{|l|l|l|l|}
\hline $\begin{array}{l}\text { Descriptive } \\
\text { Statistics }\end{array}$ & Part- A & Part-B & $\begin{array}{l}\text { PSYCHOLOGICAL } \\
\text { PROBLEMS }\end{array}$ \\
\hline Mean Score & 14.95 & 17.48 & 32.43 \\
\hline S.D. & 4.253 & 4.432 & 6.312 \\
\hline Median Score & 15 & 19 & 32 \\
\hline Max Possible & 32 & 44 & 76 \\
\hline Mean Percentage\% & 46.71 & 39.73 & 42.67 \\
\hline
\end{tabular}

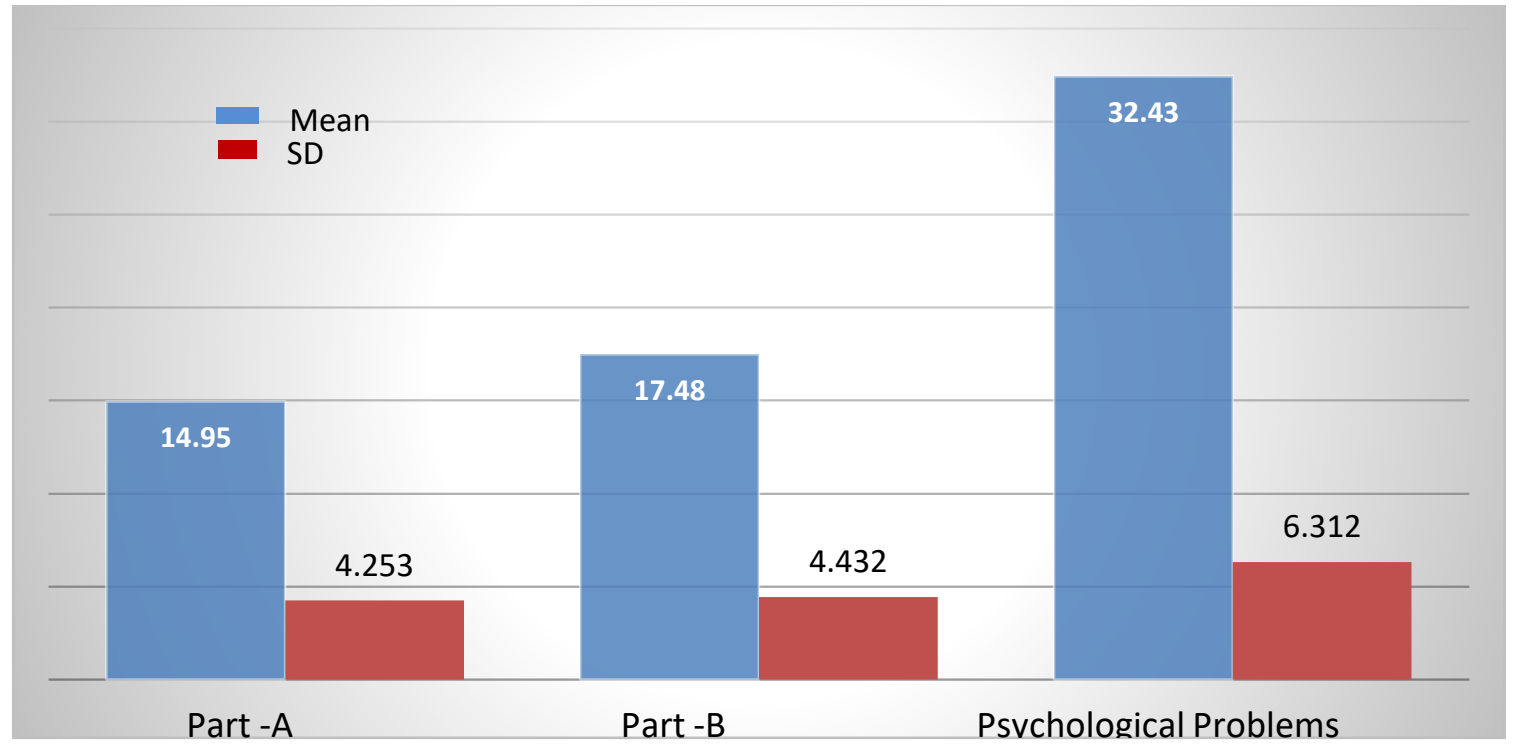

Figure 2: Descriptive Statistics of Area wise analysis of psychological problems in parents of mentally retarded

Table no. 4 depicts the itemwise analysis level of psychological score in parents of mentally retarded children. In which item no. 5 (reports constipation) and 20 (worry too much) have greater number of subjects in part A \& part B i.e. 44 who attempted Always option and item no. 16 (worms in stools) and 26 (becomes tense when meeting new persons or going to new places) have greater number of subjects in part A \& part B i.e. 58 and 73 respectively who attempted never option.

Table 4: Itemwise analysis level of psychological problems score in parents of mentally retarded children

\begin{tabular}{|l|l|l|l|l|}
\hline \multirow{2}{*}{ Area $>$} & $\begin{array}{l}\text { Itemwise } \\
\text { Analysis }\end{array}$ & $2(\%)$ & $1(\%)$ & $0(\%)$ \\
\hline \multirow{3}{*}{\begin{tabular}{l} 
Part- $\begin{array}{l}\text { Always=2, } \\
\text { Sometime=1, } \\
\text { Never=0) }\end{array}$ \\
\cline { 2 - 6 }
\end{tabular}} & Qno.1 & 35 & 59 & 6 \\
\cline { 2 - 6 } & Qno.2 & 16 & 55 & 29 \\
\cline { 2 - 6 } & Qno.3 & 12 & 57 & 31 \\
\cline { 2 - 6 } & Qno.5 & 44 & 42 & 14 \\
\cline { 2 - 6 } & Qno.6 & 21 & 70 & 9 \\
\hline
\end{tabular}




\begin{tabular}{|c|c|c|c|c|}
\hline & Qno.7 & 20 & 59 & 21 \\
\hline & Qno.8 & 23 & 47 & 30 \\
\hline & Qno.9 & 5 & 52 & 43 \\
\hline & Qno.10 & 17 & 44 & 39 \\
\hline & Qno.11 & 39 & 61 & 0 \\
\hline & Qno.12 & 10 & 57 & 33 \\
\hline & Qno.13 & 6 & 70 & 24 \\
\hline & Qno.14 & 10 & 60 & 30 \\
\hline & Qno.15 & 2 & 96 & 2 \\
\hline & Qno.16 & 0 & 42 & 58 \\
\hline \multirow{22}{*}{$\begin{array}{l}\text { Part-B } \\
(\text { True }=2, \\
\text { Somewhat } \\
\text { True }=1 \text {, } \\
\text { Untrue }=0 \text { ) }\end{array}$} & Qno.17 & 18 & 53 & 29 \\
\hline & Qno.18 & 8 & 80 & 12 \\
\hline & Qno.19 & 19 & 72 & 9 \\
\hline & Qno.20 & 44 & 42 & 14 \\
\hline & Qno.21 & 16 & 36 & 48 \\
\hline & Qno.22 & 34 & 56 & 10 \\
\hline & Qno.23 & 20 & 80 & 0 \\
\hline & Qno.24 & 6 & 57 & 37 \\
\hline & Qno.25 & 2 & 39 & 59 \\
\hline & Qno.26 & 0 & 27 & 73 \\
\hline & Qno.27 & 6 & 76 & 18 \\
\hline & Qno.28 & 10 & 30 & 60 \\
\hline & Qno.29 & 23 & 52 & 25 \\
\hline & Qno.30 & 30 & 70 & 0 \\
\hline & Qno.31 & 0 & 26 & 74 \\
\hline & Qno.32 & 7 & 28 & 65 \\
\hline & Qno.33 & 20 & 59 & 21 \\
\hline & Qno.34 & 0 & 52 & 48 \\
\hline & Qno.35 & 34 & 23 & 43 \\
\hline & Qno.36 & 24 & 44 & 32 \\
\hline & Qno.37 & 16 & 62 & 22 \\
\hline & Qno.38 & 0 & 14 & 86 \\
\hline
\end{tabular}

The results also revealed that there was no significant association between psychological problems score and the socio- demographic variables such as age, sex, marital status, education, occupation, monthly family income, religion, type of family, age 
of children, sex of children and level of mental retardation of children.

\section{DISCUSSION:}

Present study finding shows that majority of parents $(85.6 \%)$ had average (26-50) psychological problems score with mean \pm SD score of parents was $32.43 \pm 6.312$. These findings are supported by a study conducted by Singhi, Pratibha, D et al. (2008) on psychological problems faced by parents and other family members in 50 families with a physically disabled child (PD group), 50 with a mentally retarded child (MR group) and 50 with a healthy child (control group) in Chandigarh. Families with disabled children perceived greater financial stress, frequent disruption of family routine and leisure, poor social interaction, and ill effects on their physical and mental health as compared to families of control children. The overall social burden scores were significantly higher in both the groups with disabled children as compared to controls (mean scores PD 17.8, MR 14.6, C $0.72, p<.001)$. The neuroticism scores were also significantly higher (PD 23.7, MR 19.0, C 9.6, $p<.01$ ) in families with disabled children.

Present findings revealed that no significant association between psychological problems and socio-demographic variables of parents such as age, sex, marital status, education, occupation, monthly family income, religion, type of family and age, sex and level of mental retardation of children. On the contrary, some findings of study conducted by Khamis, V. (2008) to identify predictors of parental stress and psychological distress among parents of children with mental retardation in United Arab Emirates stated that the age of the child was significantly associated with parents' feelings of distress and psychiatric symptom status, and parental stress was less when the child was older. Lower socioeconomic level was associated with greater symptom rates of cognitive disturbance, depression, anxiety, and despair among parents.

\section{NURSING IMPLICATIONS :}

\section{NURSING EDUCATION}

The findings of the study can be utilized to prepare health teaching material to control psychological problems of parents of mentally retarded children and accordingly provide care; guidance and teaching to parents of mentally retarded children. As parents health may have an impact on care of mentally retarded. In nursing curriculum, awareness about psychological problems and coping strategies should be added.

\section{NURSING SERVICES}

The findings of the study will help to the health care organization to control psychological problems and manage the problems of parents of mentally retarded children. Nursing professionals should render services according to the changing needs of the society. There is need for the health personals to take active part in providing health education to parents of mentally retarded children regarding psychological problems and coping strategies.

\section{NURSING ADMINISTRATION}

The findings of the study can be utilized by the administrator of health organization/MR centers to identify the psychological problems of parents of mentally retarded children and how to adopt the coping strategies to live a healthy life. Nursing administration should anticipate the need of time and prepare young nurses to serve the community regarding psychological problems of parents of mentally retarded children. Nursing administrators can plan in-service programmes to educate the school nurses regarding psychological problems and coping strategies.

\section{NURSING RESEARCH}

The findings of the study can be utilized for conducting further research to assess psychological problems in parents of mentally retarded children. The same study can be replicated and the data can be used to disseminate to a large population on parents of mentally retarded children. The research methodology, tools and findings of the study and guidelines can be added to nursing literature. It may serve as referral material for health personal and researchers.

\section{CONCLUSION}

Parents of mentally retarded children may avoid social contacts due to fear of embarrassment or rejection. They may hardly find time for recreation or leisure due to caring responsibilities. Some parents may feel rejected or neglected from their own family members, and some may get adequate support also. Probably the unity, strength and support within the family are important factors, which influence the nature of coping.

Based on the findings of the present study the conclusions drawn were the parents experience varying degree of psychological problems. The majority of parents had average psychological problems scores and very few had low psychological problems. When level of mental retardation in children were compared with psychological problems score in parents, severe MR children's parents experienced, psychological problems more than Mild and Moderate MR Children's parents.

Financial support and sponsorship: The present research study did not receive any specific grant from funding agencies in the public, commercial, or not-for-profit sectors.

Conflicts of interest: The authors declare they have no conflicts of interest.

\section{Acknowledgments}

We thank to all the parents and health care professionals of MR centers, who directly or indirectly helped in data collection and other support during this research study.

\section{ABOUT THE AUTHORS:}

Dr. SAPNA SINGH, Ph.D(Nursing). RN.RM. Professor and HOD Paediatric Nursing in Narayan Nursing College, Gopal Narayan Singh University, Jamuhar, Rohtas, Bihar. She has Completed her Bachelor's degree in B.Sc. Nursing (Honours) from National Institute of Nursing Education, P.G.I.M.E.R. Chandigarh in 2005. She has been awarded with M.Sc Nursing (Paediatrics) from RGUHS, Bangalore, Karnataka in 2012. She is 
done Ph.D Nursing from Himalayan University, in 2018. She is having 14.5 years of teaching experience. She has published many research studies \& review articles in many International and National journals. She has been guide for many researches of Ph.D nursing, M.Sc. nursing and B.Sc. Nursing students. She is member of many research society i.e. NSS, NRSI, CNRS, GFNPSS.

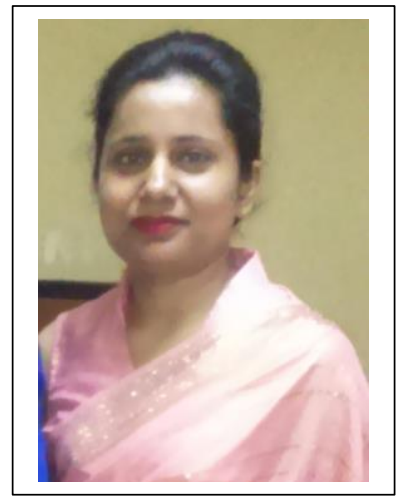

Dr. SHAMA LOHUMI, Ph.D.(Psychology), Principal, Shivalik Institute of Nursing, Sanjauli, Shimla, Himachal Pradesh. She has completed $\mathrm{PhD}$ in Psychology from Panjab University, Chandigarh(2009), M.Sc. Nursing ( Community Health Nursing) from PGI Chandigarh(1989), M.A. in English Literature from Panjab University, Chandigarh(1986) and B,Sc, Nursing from PGI Chandigarh(1982). She is having more than 30 years of teaching experience. She is guide for Ph.D nursing students of many universities. She has been speakers for many International and National conferences. She has published many articles and research papers in International and National journals. She is paper setter of many nursing subjects of various universities.

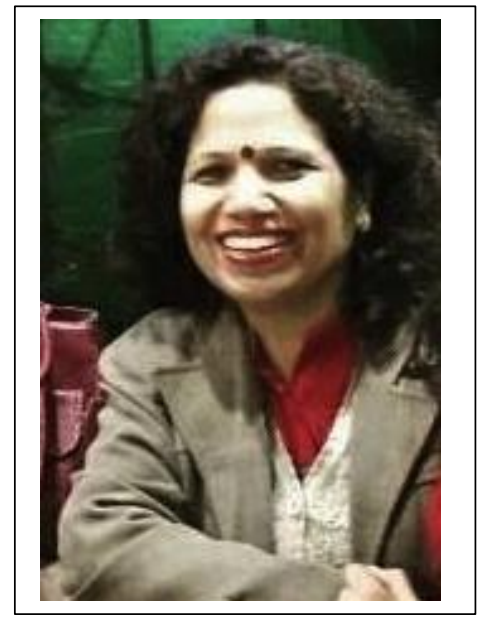

\section{REFERENCES}

[1] Boyd, J. Lucy. (August 14 2017). Problems Faced by Parents of Mentally Retarded Children. $\quad$ Retrieved from https://www.livestrong.com/article/79436-problems-faced-parentsmentally-challenged/.

[2] Chandorkar, Hemant., \& Chakraborty, P.K. (2000). Psychological morbidity of parents of mentally retarded children. Indian journal of psychiatry, 42(3), 271-274. Retrieved from https://pdfs.semanticscholar.org/ecf6/157997bc86e246a90d2fb1b87664d5e e882a.pdf.

[3] Crowe, T.K., Cunningham, Sabo. L.D., Helitzer, D.L., \& VanLeit, B. (2002). Perceived changes in self-image and coping strategies of mothers of children with disabilities. Occupational Therapy Journal of Research, 22(1), 25-33. doi:10.1177/153944920202200104.

[4] Heykyung, Oh., \& Lee, Eun-Kyoung. Othelia. (2009). Caregiver Burden and Social Support among Mothers Raising Children with Developmental Disabilities in South Korea. International Journal of Disability, Development and Education, 56(2), 149-167. doi:10.1080/10349120902868624.

[5] Islam, Md. Ziaul., Farjana, Sharmin., \& Shahnaz, Runa. (2013). Stress among Parents of Children with Mental Retardation. Bangladesh Journal of Medical Science. 12(1), 74-80. Retieved from https://www.banglajol.info/index.php/BJMS/article/view/13354

[6] Majumdar, M., Pereira, Silva. D. Y., \& Fernandes, J. (2005). Stress and anxiety in parents of mentally retarded children. Indian Journal of Psychiatry, 47(3), $144 \quad-147 . \quad$ Retrieved from http://www.ncbi.nlm.nih.gov/pmc/articles/PMC2919789/.

[7] Mohamed, G. Al-Kuwari. (2007). Psychological health of mothers caring for mentally disabled Children in Qatar. Neurosciences, 12(4), 312-317. Retrieved from https://pdfs.semanticscholar.org/e8b2/966fd0923c9a5fac2bde2ad42a8b1711 d64c.pdf.

[8] Nagarkar, Amit., Sharma, Jagdish. Prashad., Tandon, S. K., \& Goutam, Pritesh. (2014). The clinical profile of mentally retarded children in India and prevalence of depression in mothers of the mentally retarded. Indian Journal of Psychiatry, 56(2), 165-170. doi:10.4103/0019-5545.130500.

[9] Parameswari, S., \& Eljio, J.O. Jeryda. Gnanajane. (2010). Study on Psychological Well Being among the Parents of Children with Intellectual and Developmental Disabilities. Research paper presented at the International Conference on Well Being of Children, Youth and Adults: A Global Social Work perspective. Abstract retrieved from https://pdfs.semanticscholar.org/88ee/ddde7e2df5ef81e5e20daaaf843c2b37 7858.pdf.

[10] Roos, Philip. (1977). Parents of mentally retarded people. International Journal of Mental Health, 6(1), 96-119. Retrieved from https://mn.gov/mnddc/parallels2/pdf/70s/77/77-IJH-NAC_Chapter_6.pdf.

[11] Upadhyaya, G. R., \& Havalappanavar, N.B. (2008). Stress in parents of mentally retarded children. Journal of the Indian Academy of Applied Psychology, 34, 53-59. Retrieved from http://medind.nic.in/jak/t08/s1/jakt08s1p53.pdf.

[12] World Health Organization, Geneva. (1996). The International Classification of Diseases, 10th Revision (ICD-10) guide for Mental Retardation, Division of mental health and prevention of substance abuse, 96(3). Retrieved from http://www.who.int/mental_health/media/en/69.pdf.

\section{AUTHORS}

First Author - Dr. Sapna Singh, Professor, Head of Department Paediatric Nursing, Narayan Nursing College, Gopal Narayan Singh University, Rohtas, Bihar. India.

Second Author - Dr. Shama Lohumi, Principal, Shivalik Institute of Nursing, Sanjauli, Shimla, Himachal Pradesh. India.

Correspondence Author - E-mail:sapna49@gmail.com 
International Journal of Scientific and Research Publications, Volume 11, Issue 10, October 2021

This publication is licensed under Creative Commons Attribution CC BY. 